\title{
Effects of Polychlorinated Biphenyls (PCBs) on a Marine Plankton Population and Sedimentation in Controlled Ecosystem Enclosures
}

\author{
K. Iseki ${ }^{1 *}$, M. Takahashi ${ }^{2}$, E. Bauerfeind ${ }^{3}$ and C. S. Wong ${ }^{1 *}$ \\ ${ }^{1}$ Ocean Chemistry Division and Marine Carbon Research Centre, Institute of Ocean Sciences, P.O. Box 6000, Sidney, B.C., V8L \\ 4 B2 Canada \\ ${ }^{2}$ Institute of Biological Sciences, The University of Tsukuba, Sakura-mura, Ibaraki, 305 Japan \\ ${ }^{3}$ Institut für Meereskunde an der Universität Kiel, Düsternbrooker Weg 20, D-2300 Kiel, Federal Republic of Germany
}

\begin{abstract}
Effects of polychlorinated biphenyls (PCBs) on a natural marıne ecosystem were studied employing controlled ecosystem enclosures (CEEs) which contained $68 \mathrm{~m}^{3}$ of seawater and the natural sea-water biota (Saanich Inlet, British Columbia, Canada). Following addition of PCBs (50 $\mu \mathrm{gs} 1^{-1}$ ) to a CEE, primary productivity was initially reduced by PCBs to less than $30 \%$ of the control CEE to which no PCBs had been added. Settling velocity of particulate matter was initually accelerated by PCB addition, but gross sedimentation decreased due to inhibition of primary productivity. Decomposition activity in sedimented matter was initially inhibited by PCBs, one order of magnitude lower than that of the control, but followed by recovery to the control level within 6-10 d. Drastic and chronic reductions in the size of zooplankton stocks were also attributed to PCB stress.
\end{abstract}

\section{INTRODUCTION}

Polychlorinated biphenyls (PCBs) are widespread and persistent pollutants of the environment (Risebrough et al., 1968). They have been detected in seawater (Bidlman and Olney, 1974), marine sediments (Pavlou and Dexter, 1979) and various species of organisms (Jansson et al., 1975) throughout the world.

Toxicological studies revealed low acute toxicity of $\mathrm{PCBs}$ to aquatic invertebrates and vertebrates (Duke et al., 1970; Hansen et al., 1974). But it has been reported that PCBs inhibited the growth in several algal species and changed the species composition of algae in laboratory (Mosser et al., 1972) as well as in natural water ( $O^{\prime}$ Connors et al., 1978). Most of these studies were done with single species in the laboratory, however, little is still known about the overall effects of PCBs on the pelagic plankton community through material cycling.

- Present address: Seakem Oceanography Ltd., 9817 West Saanich Road, Sidney, B.C., V8L 3S1 Canada

- Addressee for correspondence
The Controlled Ecosystem Pollution Experiment (CEPEX) was one approach of reducing the gap between laboratory and field situations with large plastic bags (Menzel and Case, 1977). The present study describes some effects of PCBs on a plankton population in a marine ecosystem, employing controlled ecosystem enclosures. Observations on the behaviour and pathways of PCBs within the enclosure are discussed in a separate paper (Wong et al., 1981).

\section{MATERIALS AND METHODS}

Natural plankton populations of Saanich Inlet, British Columbia, Canada were captured on August 19, 1978 in two controlled ecosystem enclosures (CEEs, 68 $\mathrm{m}^{3}$ in volume). Each CEE was constructed of an acrylic floating ring, $2.5 \mathrm{~m}$ in diameter, from which a top-open cylinder bag made of polyethylene sheet was hung. CEE deployment and the general design are described in detail by Menzel and Case (1977). On August 22, a mixture of PCBs (Aroclor 1254), dissolved in $50 \mathrm{ml}$ of ethanol and $15 \mathrm{~g}$ non-toxic dispersant (Corexit 9527), was mixed with 261 of seawater pumped from inside 
the CEE and was added to the CEE at a final concentration of $50 \mu \mathrm{g} \mathrm{l}^{-1}$ (CEE E) using a technique (a diffusion ring) similar to that described by Topping and Windom (1977) The other enclosure serving as a control (CEE F) received equal amounts of ethanol and the dispersant. Nutrients were added thoroughly in the top $10 \mathrm{~m}$ of the water column using the diffusion ring in both CEEs on August 29. Nominal concentrations of nutrients were $10 \mu \mathrm{g} \cdot$ at $\mathrm{N}^{-1}$ of nitrate, $10 \mu \mathrm{g}$-at Si $l^{-1}$ of silicate, and $1.0 \mu \mathrm{g}$-at $\mathrm{P} \mathrm{I}^{-1}$ of phosphate.

Water samples for the measurements of chlorophyll $a$ (Chl a), photosynthetic activity and particulate organic carbon (POC) were collected by a peristaltic pump at three integrated depth intervals of $0-5,5-10$ and 10-13 m. For nutrient determinations, discrete depth samples of 3 and $10 \mathrm{~m}$ were also obtained by pumping.

Fluorometry using a Turner 111-003 fluorometer (Strickland and Parsons, 1972) was applied for Chl a determinations. Primary productivity was determined using ${ }^{14} \mathrm{C}$ bi-carbonate for $24 \mathrm{~h}$ in situ incubation at middle sampling depths in each CEE. POC in particles retained on pre-combusted Whatman GF/C glass-fiber filters was determined with a Perkin-Elmer elemental analyzer (Model 240). Nitrate, phosphate and silicate were analyzed by the methods described by Strickland and Parsons (1972) using a Technicon autoanalyzer II. Salinity was determined with a salinometer (Model 8400, Guildline Instruments).

A sediment trap was hung at $13 \mathrm{~m}$ in each enclosure to collect settling materials. The trap was made of two PVC cylinders, $48 \mathrm{~cm}$ high and $12.5 \mathrm{~cm}$ across the mouth (Fig. 1). A baffle grid $(1.3 \mathrm{~cm}$ of each compartment and $5.0 \mathrm{~cm}$ in height) was placed at the opening of each cylinder in order to reduce distorting effects of currents in or near the upper part of the cylinder and to prevent animals from invading the cylinder. The same type of grid was placed in a sampling chamber made of acrylic in each cylinder, to prevent disturbance and aggregation of collected particles. Two drain spigots on the side of the cylinder allowed the water to escape after trap recovery.

After thorough gentle mixing of sedimented matter, collected in each sampling chamber, the content was divided into 4 aliquots for measurements of dry weight, POC and PON, decomposition rate and for visual observation with a light microscope. PON was determined by the same procedure, described earlier, as POC.

The decomposition rate of the sedimented matter was determined from the increase in total $\mathrm{CO}_{2}$ in a sedimented-matter/seawater mixture kept in a $125 \mathrm{ml}$ Erlenmeyer flask, which had a flare and was tightly sealed with a ground-glass stopper, during $24 \mathrm{~h}$ incubation in dark at surface temperature. Before incubation, $100 \mathrm{mg} \mathrm{HgCl}_{2}$ were added into a flask as a blank.

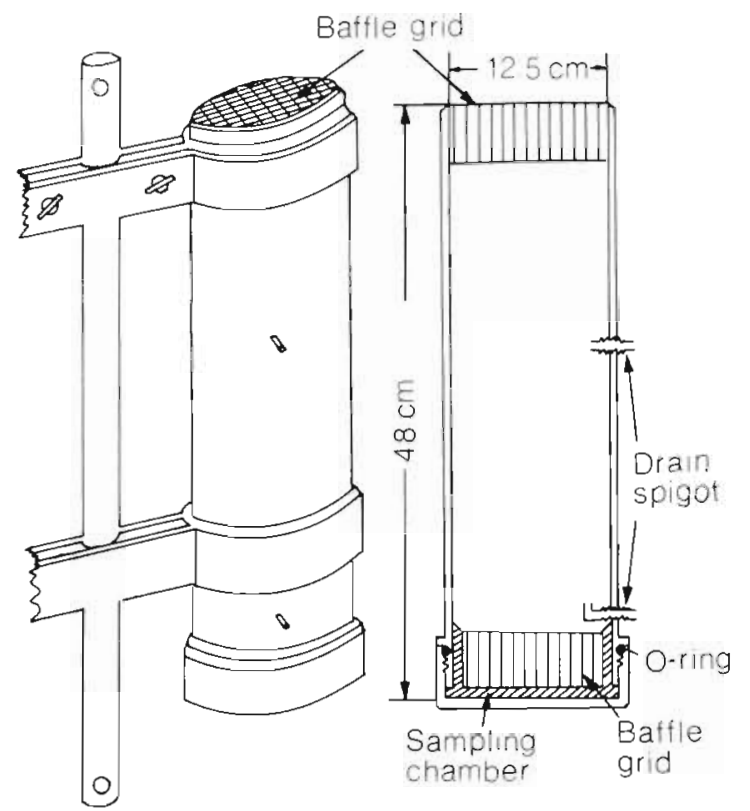

Fig. 1. Sediment trap used in this study

After incubation, a $1 \mathrm{ml}$ sample was removed from each flask with a $1 \mathrm{ml}$ syringe, injected into $1 \mathrm{ml}$ sulphuric acid (pre-purged with nitrogen) in a $5 \mathrm{ml}$ glass ampule through a rubber septum, and purged with nitrogen. The $\mathrm{CO}_{2}$ released was then analyzed by an infrared analyzer (Total Carbon System, Model 0524B. Oceanography International Corp.). Assuming that decomposition processes are logarithmic with time, the decomposition coefficient of sedimented matter $(k$, $\left.\mathrm{d}^{-1}\right)$ during the incubation period $(t, \mathrm{~d})$ was calculated as

$$
k=-\frac{1}{t} \ln \frac{C o-\Delta C}{C o}
$$

where $C_{0}=$ initial POC amount of sedimented matter, $\Delta C=$ decreased amount of sedimented matter determined by the $\mathrm{CO}_{2}$ released during $t \mathrm{~d}$. Assuming that gross sedimentation rate $\left(F, m g C \mathrm{~m}^{-2} \mathrm{~d}^{-1}\right)$ and decomposition coefficient of sedimented matter ( $k$, $\left.\mathrm{d}^{-1}\right)$ are constant during collecting time period $(t, d)$, time dependent change $(d A / d t)$ of apparent sedimented matter $\left(A, \mathrm{mg} \mathrm{C} \mathrm{m}^{-2}\right)$, collected actually in sediment trap, can be described as

$$
\frac{d A}{d t}=F-k A
$$

Integrating Equation 2 with time $t$ under the initial condition, $\mathrm{A}=\mathrm{O}$ at $t=\mathrm{O}$

$$
A=\frac{F}{k}\left(1-e^{-k i}\right)
$$


By rearranging Equation 3, gross sedimentation rate $F$ is described as

$$
F=\frac{A K}{1-e^{-k i}}
$$

Gross sedimentation during the suspension period $(t)$ can be described as $F t$ ( $\mathrm{mg} \mathrm{C}^{-2}$ ), and $F t-A$ defined as total decomposition loss $D$ during the suspension period. Iseki et al. (1980) considered the biochemical decomposition of sedimented matter in a sediment trap in more detail.

\section{RESULTS}

\section{Initial Condition of CEEs}

Although both CEEs were operated almost simultaneously, the amount of water captured was different; it was 95 and $75 \%$ for CEEs $E$ and $F$, respectively. The remaining water was pumped from $5 \mathrm{~m}$ into the surface of each CEE. This treatment created some modifications in environmental parameters (Table 1). There was an inverse relation between the water capture

Table 1. Initial conditions in two CEEs. All data obtained on August 20, except for salinity (August 21) and nitrate (August 22)

\begin{tabular}{|c|c|c|c|c|}
\hline \multirow{2}{*}{$\begin{array}{c}\text { Environmental } \\
\text { parameters }\end{array}$} & \multirow{2}{*}{$\begin{array}{l}\text { Sampling } \\
\text { depth (m) }\end{array}$} & \multicolumn{2}{|c|}{ CEEs } & \multirow[t]{2}{*}{ Outside } \\
\hline & & E & F & \\
\hline \multicolumn{5}{|l|}{$\begin{array}{l}\text { Water capture } \\
\text { percentage }\end{array}$} \\
\hline \multirow[t]{4}{*}{ Salinity $(\%)$} & 0 & 29.36 & 29.36 & 29.17 \\
\hline & 5 & 29.43 & 29.37 & 29.40 \\
\hline & 10 & 29.44 & 29.44 & 29.48 \\
\hline & 13 & 29.59 & 29.52 & 29.51 \\
\hline \multirow{3}{*}{ 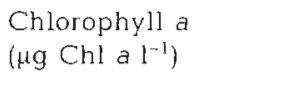 } & $0-5$ & 3.8 & 3.3 & 6.5 \\
\hline & $5-10$ & 2.5 & 2.1 & 0.9 \\
\hline & $10-13$ & 0.9 & 0.8 & 0.2 \\
\hline \multirow{3}{*}{$\begin{array}{l}\mathrm{POC} \\
\left.(\mu \mathrm{g} \mathrm{C}]^{1}\right)\end{array}$} & $0-5$ & 171 & 146 & 277 \\
\hline & $5-10$ & 115 & 101 & 61 \\
\hline & $10-13$ & 72 & 54 & 41 \\
\hline \multirow{3}{*}{$\begin{array}{l}\text { Primary productivity } \\
\left.\text { (mg } C \mathrm{~m}^{-3} \mathrm{~d}^{-1}\right)\end{array}$} & $0-5$ & 228 & 242 & - \\
\hline & $5-10$ & 51 & 37 & - \\
\hline & $10-13$ & 7 & 2 & - \\
\hline \multirow{3}{*}{ 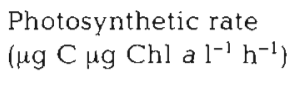 } & $0-5$ & 2.5 & 3.1 & - \\
\hline & $5-10$ & 0.9 & 0.7 & - \\
\hline & $10-13$ & 0.3 & 0.1 & - \\
\hline \multirow[t]{3}{*}{ POC: Chl a ratio } & $0-5$ & 45 & 45 & 42 \\
\hline & $5-10$ & 47 & 49 & 65 \\
\hline & $10-13$ & 77 & 71 & 274 \\
\hline Nitrate & 3 & 0.2 & 2.5 & - \\
\hline$\left(\mu \mathrm{g}-\mathrm{at} \mathrm{N}^{-1}\right)$ & 10 & 14.2 & 12.9 & - \\
\hline \multicolumn{5}{|l|}{ - Not observed } \\
\hline
\end{tabular}

percentage and concentrations of $\mathrm{Chl} a$ and $\mathrm{POC}$ in the top $10 \mathrm{~m}$ of the water column.

POC: Chl a ratios of CEEs $E$ and $F$ were similar, being $45-49$ in the upper $10 \mathrm{~m}$. Initial photosynthetic rates were almost proportional to the amount of water pumped into each CEE. This was explained partly by higher nitrate levels observed in the heavily pumped CEE, $2.5 \mu \mathrm{g}$-at $\mathrm{N} \mathrm{l}^{-1}$ for CEE F, which was compared with $0.2 \mu \mathrm{g}$-at $\mathrm{N}^{-1}$ in CEE E.

\section{Changes of Environmental Parameters}

Salinity varied from 29.4 to $28.8 \% \mathrm{~S}$ at the surface but was almost constant $(29.4 \% \mathrm{~S})$ at $10 \mathrm{~m}$ in CEE E throughout the experiment. A similar trend was observed in CEE F. At the beginning of the experiment, nitrate concentrations in both CEEs showed some differences at $3 \mathrm{~m}$ due to different pumping rates (Fig. 2). Nitrate was depleted within $3 \mathrm{~d}$ after capture at $3 \mathrm{~m}$ in CEE $\mathrm{E}$, but was not depleted until $6 \mathrm{~d}$ in $\mathrm{CEE}$ F. Initial nitrate concentrations at $10 \mathrm{~m}$ were all high (12.9-14.2 $\mu \mathrm{g}$-at $\mathrm{N}^{-1}$ ); they decreased quickly in the control (CEE F), but slowly in CEE E. By adding nutrients on August 29, final concentrations of 11.6-11.7 $\mu \mathrm{g}$-at $\mathrm{N}^{-1}$ at $3 \mathrm{~m}$ were achieved. Seven days after nutrient addition, nitrate concentrations at $3 \mathrm{~m}$ decreased to $2.4-3.3 \mu \mathrm{g}$-at $\mathrm{N}^{-1}$ in both CEEs. There was a consistent decrease of nitrate at $10 \mathrm{~m}$ between September 5 and 11 in CEE E whereas no remarkable change was observed in CEE F. Overall changing patterns of phosphate and silicate were similar to those of nitrate.

Immediately after launching, $\mathrm{Chl}$ a started to increase in both CEEs, particularly obvious in the upper $10 \mathrm{~m}$ reaching a maximum within $4 \mathrm{~d}$ (Fig. 3). Maximum concentrations of $\mathrm{Chl} a$ in the top $5 \mathrm{~m}$, observed on August 23, were 13.0 and $24.1 \mu \mathrm{g} \mathrm{Chl} \mathrm{a} \mathrm{l}^{-1}$ in CEEs $E$ and $F$, respectively. Chl a increases within the first $3 \mathrm{~d}$ were 7.4 fold in CEE F and 3.4 fold in CEE

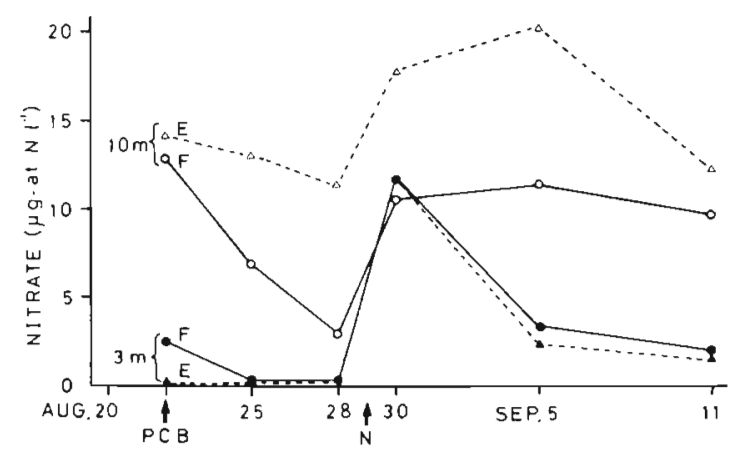

Fig. 2. Changes in nitrate concentrations at 3 and $10 \mathrm{~m}$ in CEEs $\mathrm{E}$ and $\mathrm{F}$. Arrows marked 'PCB' and ' $\mathrm{N}$ ' indicate PCB and nutrient addition, respectively 


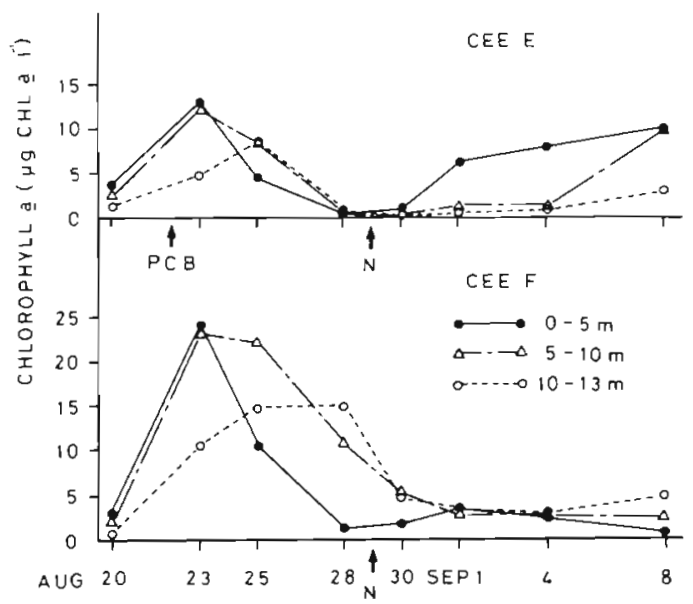

Fig. 3. Changes in chlorophyll a at three different depth intervals in CEEs $E$ and $F$. Arrows marked 'PCB' and ' $N$ ' indicate $\mathrm{PCB}$ and nutrient addition, respectively

E. After August 23, Chl a above $5 \mathrm{~m}$ in both CEEs declined sharply to the level of $0.5-1.4 \mu \mathrm{g} \mathrm{Chl} \mathrm{a} \mathrm{I}^{-1}$. Nutrient addition on August 29 reincreased Chl a above $5 \mathrm{~m}$ in both CEEs. The increase was pronounced in CEE E which was maintained until the end of the experiment.

Initial Chl a increase was accompanied by an increase in POC but their temporal changing patterns were slightly different (Fig. 4). POC maximum above $5 \mathrm{~m}$ occurred on August 25, 2 d after the Chl a maximum, and then declined as did Chl a. Such phase differences in changing patterns between POC and Chl a were not obvious during the later part of the experiment.

On August 20, POC in the water column consisted mainly of small-size particles, less than $35 \mu \mathrm{m}$ (Table $2)$. The relative abundance of small particles $(<35 \mu \mathrm{m})$ decreased markedly during the algal bloom between August 23 and 25 in both CEEs and increased again in PCB-treated CEE E after August 28. The small-particle fraction persisted throughout the rest of experiment in PCB-treated CEE E. Contrary, large particles were abundant in the control CEE F between August 23 through September 1, followed by a gradual decrease

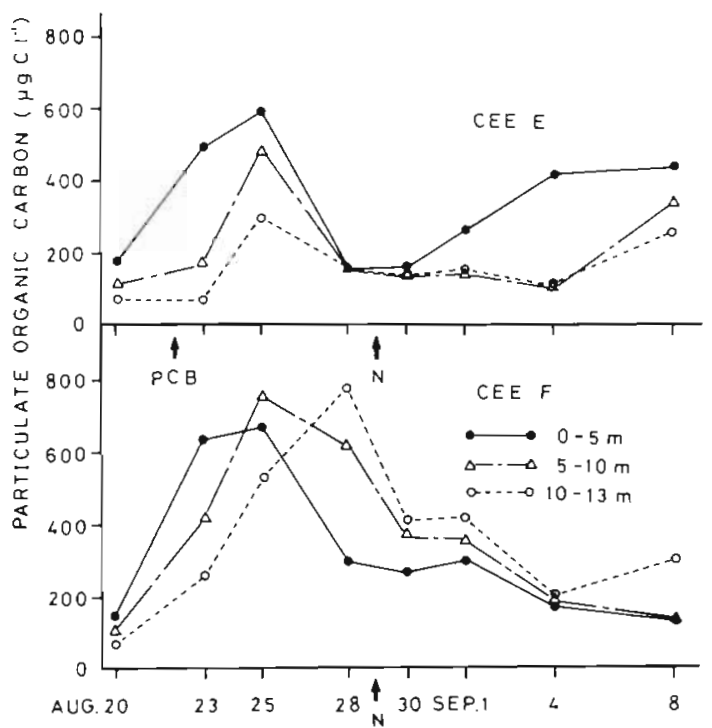

Fig. 4. Changes in POC at three different depth intervals in CEEs $\mathrm{E}$ and F. Arrows marked 'PCB' and ' $\mathrm{N}$ ' indicate PCB and nutrient addition, respectively

to $24 \%$ towards the end of the experiment. The phytoplankton was primarily composed of centric and pennate diatoms on August 23 in both CEEs, but microflagellates became abundant in CEE E after August 28 (152 diatom cells vs. 5817 microflagellate cells $\mathrm{ml}^{-1}$ on September 2). In CEE F, microflagellates were also abundant but less significant compared to CEE E (991 diatom cells vs 1682 microflagellate cells $\mathrm{ml}^{-1}$ on September 2). Two weeks after PCB addition (September 6) total zooplankton numbers (comprised mainly of Paracalanus parvus) in the water column above $10 \mathrm{~m}$ were two orders of magnitude lower in PCB-treated CEE $E$ than that in CEE F. CEEs $E$ and $F$ contained 80 and 3000 individuals $\mathrm{m}^{-3}$, respectively.

\section{Changes in Biological Activities}

Immediately after PCB addition, primary productivity in CEE E decreased from 1.42 to $0.32 \mathrm{~g} \mathrm{C} \mathrm{m}^{-2} \mathrm{~d}^{-1}$ ( $73 \%$ decrease) and maintained a low level until

Table 2. Relative abundance of POC, in two different size fractions, i.e. larger or smaller than $35 \mu \mathrm{m}$ at $0-5 \mathrm{~m}$ depth $1 \mathrm{n} \mathrm{CEEs} \mathrm{E}$ and $\mathrm{F}$

\begin{tabular}{|c|c|c|c|c|c|c|c|c|c|}
\hline \multirow[t]{2}{*}{ CEE } & \multirow[t]{2}{*}{ Size $\left(\mu m_{i}\right)$} & \multicolumn{8}{|c|}{ Sampling date } \\
\hline & & Aug 20 & Aug. 23 & Aug. 25 & Aug. 28 & Aug. 30 & Sept. 1 & Sept. 4 & Sept. 8 \\
\hline \multirow{2}{*}{$\mathrm{E}$} & $35<$ & 28 & 57 & 58 & 8 & 6 & 5 & 7 & 3 \\
\hline & $<35$ & 72 & 43 & 42 & 92 & 94 & 95 & 93 & 97 \\
\hline \multirow{2}{*}{$\mathrm{F}$} & $35<$ & 26 & 67 & 69 & 60 & 56 & 55 & 42 & 24 \\
\hline & $<35$ & 74 & 33 & 31 & 40 & 44 & 45 & 58 & 76 \\
\hline
\end{tabular}




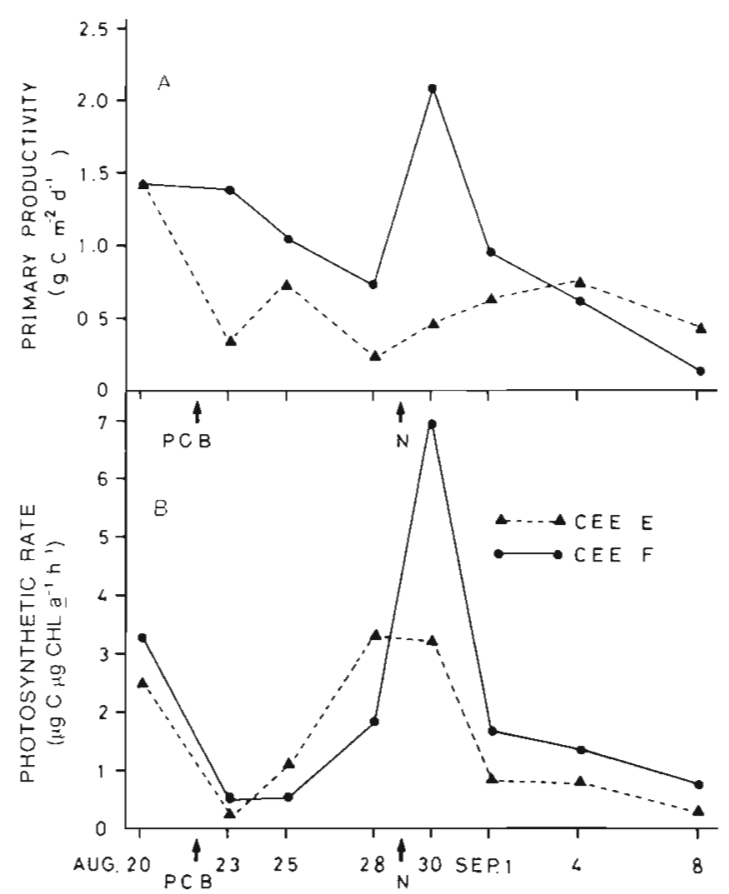

Fig. 5. Changes in primary productivity in the upper $13 \mathrm{~m}$ (A) and photosynthetic rate in $0-5 \mathrm{~m}(\mathrm{~B})$ in $C E E_{5} \mathrm{E}$ and $\mathrm{F}$. Arrows marked ' $P C B$ ' and ' $N$ ' indicate $P C B$ and nutrient addition, respectively

August 28 (Fig. 5A). In contrast, no decline of productivity was noticed in CEE F (control) during August 20 and 23 , but thereafter productivity gradually decreased until nutrient addition. After nutrient addition, the productivity in CEE $F$ showed a remarkable enhancement, but in CEE E only gradual increase was observed.

However, there was not much difference between the two CEEs in regard to changes in photosynthetic rates (Fig. 5B). In both CEEs photosynthetic rates decreased during the first $3 \mathrm{~d}$ and then gradually increased during the next $5 \mathrm{~d}$. A sudden increase in photosynthetic rate was observed in CEE F after nutrient addition attained 3.9 times $(1.8$ to $7.0 \mu \mathrm{g} \mathrm{C} \mu \mathrm{g} \mathrm{Chl}$ $a^{-1} h^{-1}$ ). However, enhancement effects by nutrient addition were less significant in CEE E. Photosynthetic rates decreased sharply from August 30 to September 1 in both CEEs and then gradually decreased until September 8. During the last $9 d$, photosynthetic rates were always higher in CEE $F$ than in CEE E.

\section{Changes in Sedimentation}

The amount of apparent sedimented matter $A$ was small and showed almost no variation between CEEs prior to the PCB addition (Table 3). Decomposition coefficients of sedimented matter $(k)$, obtained from laboratory incubation experiments, were high - ca 0.3 $\mathrm{d}^{-1}$ in August 21 samples - showing no significant difference between CEEs but decreased down to 0.1 $\mathrm{d}^{-1}$ or lower in samples collected between 23 and 28 August (Table 3). The most significant decrease of $k$ $\left(0.01 \mathrm{~d}^{-1}\right)$, was observed in CEE E immediately after PCB addition, whereas $0.09 \mathrm{~d}^{-1}$ was obtained for CEE $F$ in the same period. The decomposition coefficient of CEE E recovered to the same level of CEE $F$ in samples collected between August 28 and September 1. There was not much difference in $k$ between CEEs during the subsequent experimental period.

Sedimentation losses from the organic matter produced by primary production, expressed as the ratio of $F / P$, were low and similar in both CEEs at the beginning of experiment; thereafter they increased rapidly (Table 3). The ratio sedimentation loss to primary pro-

Table 3. Primary productivity, sedimentation, and decomposition rates of sedimented matter. $P, A, k$ observed, F, D calculated values

\begin{tabular}{|c|c|c|c|c|c|c|c|c|c|}
\hline $\begin{array}{l}\text { Sampling } \\
\text { intervals }\end{array}$ & $\begin{array}{c}t \\
\text { Suspension } \\
\text { period } \\
\text { (d) }\end{array}$ & CEE & $\begin{array}{c}P \\
\text { Primary } \\
\text { produc- } \\
\text { tivity } \\
\left(\mathrm{mg} \mathrm{C} \mathrm{m} \mathrm{m}^{-2} \mathrm{~d}^{-1}\right)\end{array}$ & $\begin{array}{c}\text { A } \\
\text { Apparent } \\
\text { sedimented } \\
\text { matter } \\
\left(\mathrm{mg} \mathrm{C} \mathrm{m}^{-2}\right)\end{array}$ & $\begin{array}{c}k \\
\text { Decom- } \\
\text { position } \\
\text { coefficient } \\
\left(d^{-1}\right)\end{array}$ & $\begin{array}{c}F \\
\text { Gross } \\
\text { sedimentation } \\
\text { rate } \\
\left(\mathrm{mg} \mathrm{C} \mathrm{m}^{-2} \mathrm{~d}^{-1}\right)\end{array}$ & $\begin{array}{c}D \\
\text { Decom- } \\
\text { position } \\
\text { loss } \\
\left(\mathrm{mg} \mathrm{C} \mathrm{m}^{-2}\right)\end{array}$ & $\begin{array}{c}F / P \times 100 \\
(\%)\end{array}$ & $D / F t \times 100$ \\
\hline $\begin{array}{l}\text { Aug. } 20 \\
\text { Aug. } 21\end{array}$ & 1 & $\begin{array}{l}E \\
F\end{array}$ & $\begin{array}{l}1420 \\
1410\end{array}$ & $\begin{array}{l}50 \\
60\end{array}$ & $\begin{array}{l}0.30 \\
0.31\end{array}$ & $\begin{array}{l}60 \\
70\end{array}$ & $\begin{array}{l}10 \\
10\end{array}$ & $\begin{array}{l}4 \\
5\end{array}$ & $\begin{array}{l}17 \\
14\end{array}$ \\
\hline $\begin{array}{l}\text { Aug. } 23 \\
\text { Aug. } 28\end{array}$ & 5 & $\begin{array}{l}E \\
F\end{array}$ & $\begin{array}{r}520 \\
1090\end{array}$ & $\begin{array}{l}1960 \\
2450\end{array}$ & $\begin{array}{l}0.01 \\
0.09\end{array}$ & $\begin{array}{l}400 \\
610\end{array}$ & $\begin{array}{r}40 \\
600\end{array}$ & $\begin{array}{l}78 \\
56\end{array}$ & $\begin{array}{r}2 \\
20\end{array}$ \\
\hline $\begin{array}{l}\text { Aug. } 28 \\
\text { Sept. } 1\end{array}$ & 4 & $\begin{array}{l}E \\
F\end{array}$ & $\begin{array}{r}410 \\
1440\end{array}$ & $\begin{array}{l}2000 \\
4160\end{array}$ & $\begin{array}{l}0.02 \\
0.02\end{array}$ & $\begin{array}{r}520 \\
1080\end{array}$ & $\begin{array}{r}80 \\
160\end{array}$ & $\begin{array}{r}127 \\
75\end{array}$ & $\begin{array}{l}4 \\
4\end{array}$ \\
\hline $\begin{array}{ll}\text { Sept. } & 1 \\
\text { Sept. } & 5\end{array}$ & 4 & $\begin{array}{l}E \\
F\end{array}$ & $\begin{array}{l}710 \\
740\end{array}$ & $\begin{array}{l}1510 \\
2770\end{array}$ & $\begin{array}{l}0.04 \\
0.05\end{array}$ & $\begin{array}{l}410 \\
760\end{array}$ & $\begin{array}{l}130 \\
270\end{array}$ & $\begin{array}{r}58 \\
103\end{array}$ & $\begin{array}{l}8 \\
9\end{array}$ \\
\hline $\begin{array}{ll}\text { Sept. } & 5 \\
\text { Sept. } & 9\end{array}$ & 4 & $\begin{array}{l}E \\
F\end{array}$ & $\begin{array}{l}560 \\
300\end{array}$ & $\begin{array}{l}1150 \\
1350\end{array}$ & $\begin{array}{l}0.13 \\
0.12\end{array}$ & $\begin{array}{l}370 \\
420\end{array}$ & $\begin{array}{l}330 \\
330\end{array}$ & $\begin{array}{r}66 \\
140\end{array}$ & $\begin{array}{l}22 \\
20\end{array}$ \\
\hline
\end{tabular}


ductivity revealed a maximum of $127 \%$ in CEE E during August 28 and September 1, followed by rapid decrease. In the control, this ratio showed a gradual increase during the experiment and reached a maximum of $140 \%$ between September 5 and 9 .

Total decomposition losses of sedimented matter during suspension, defined as $D / F t$, also revealed no significant difference between CEEs prior to $P C B$ addition (Table 3). However, it diminished extensively after PCB addition in CEE E, to $1 / 10$ of the control, between August 23 and 28, and then showed subsequent recovery by August 28 and September 1.

$\mathrm{C}: \mathrm{N}$ ratios and carbon content (POC per unit dry weight of particles) of sedimented matter varied between 6.6 and 7.2 , and 19.5 and $27.7 \%$, respectively within the two CEEs during the experiment. However, no apparent difference was observed between CEEs.

\section{DISCUSSION}

Initial PCB concentrations in the water column were about $40 \mu \mathrm{g} \mathrm{l}^{-1}$ at $1 \mathrm{~m}$ and $5 \mathrm{~m}$, and $15 \mu \mathrm{g} \mathrm{I}^{-1}$ at $10 \mathrm{~m}$ in CEE E (Fig. 6). The PCBs were not uniformly distributed throughout the water column, possibly due to uneven $\mathrm{PCB}$ addition to the water column using the diffusion ring. Almost exponential $P C B$ decrease was observed with time at 1 and $5 \mathrm{~m}$. At $10 \mathrm{~m}$, however, the PCB concentration increased within the first $2 \mathrm{~d}$ after addition, followed by subsequent decrease with time. Six days after PCB addition, the concentrations were below $15 \mu \mathrm{g} \mathrm{I}^{-1}$ at all three depths; they were highest at $10 \mathrm{~m}$ and lowest at $1 \mathrm{~m}$. It is likely that the rapid removal of PCBs from the water column is directly related to the settling of particulate matter (phytoplankton). Harding and Phillips (1978b) showed that phytoplankton is capable of rapidly accumulating substantial PCB amounts, with equilibration occurring within $2 \mathrm{~h}$.

Extraction of 3 and $10 \mathrm{~m}$ samples of bag-wall material revealed that a slight amount of Aroclor 1254 was associated with the bag walls. However, this amount was negligible, less than $0.5 \%$ of the total PCBs added (Wong et al., 1981). It is considered that PCB adsorption on the bag wall and the sediment trap was of minor importance.

After PCB addition, the diatom population initially dominating in the water was quickly replaced by microflagellates. A similar population shift was observed in other pollutant experiments using copper and mercury (Thomas and Seibert, 1977). These findings indicate that small algae are less sensitive or better able to recover from pollutant stress, compared to most of the larger phytoplankters (centric diatoms, in this case). Interspecific differences of phytoplankton in regard to

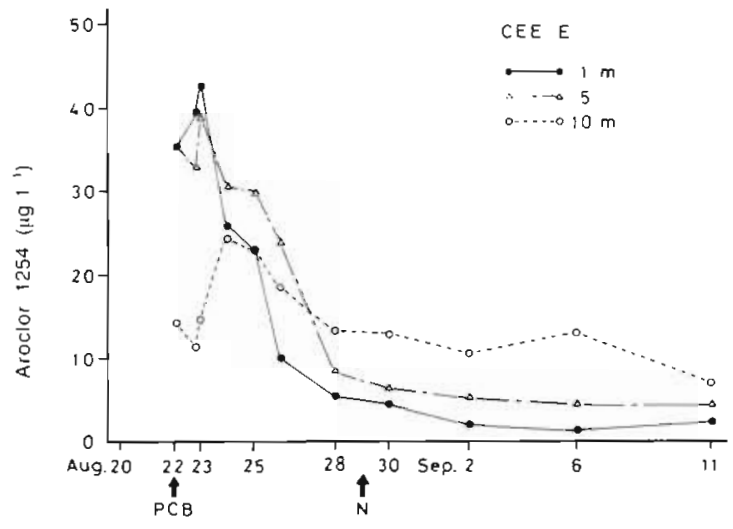

Fig. 6. Changes in Aroclor 1254 at three depths in CEE E Arrows marked 'PCB' and ' $\mathrm{N}$ ' indicate $\mathrm{PCB}$ and nutrient addition, respectively. PCBs were analyzed using HewlettPackard gas chromatography (Model 5830A) equipped with

${ }^{63} \mathrm{Ni}$ eléctron capture detector. (After Wong et al., 1981)

their PCB susceptibility are known during cell division and photosynthesis (Menzel et al., 1970). Harding and Phillips (1978a) observed that the pennate diatom Nitzschia longissima and the green alga Dunaliela tertiolecta were relatively insensitive to PCBs, both in regard to photosynthesis and cell division, although substantial inhibition was observed in centric diatoms such as Thalassiosira pseudonana, Chaetoceros socialis and Skeletonema costatum, and in some flagellates such as Monochrisis lutheri and Isochrisis galbana.

Immediately after PCB addition, an acceleration in sinking rates of materials occurred in CEE $E$; this was established on the basis of gross sedimentation rate divided by primary productivity, F/P (Table 3); however, this was not obvious in the control. Acceleration in sinking rate may possibly be attributed to direct toxicity effects of PCBs: sinking rates of senescent and dead cells are several times faster than those of growing cells (Smayda, 1970). A similar acceleration in sinking rates of particles has been observed in a copper-treated plankton population by Harrison and Davies (1977).

Following nutrient addition, photosynthetic rate and primary productivity increased significantly in CEE F (Fig. 5). However, in the upper layer of the water column the increase in Chl a and POC was less in CEE $F$ than in CEE E (Figs 3 and 4). During the week following nutrient addition, Chl $a$ and POC persisted in the upper layer in CEE E; there was no rapid settling as at the beginning of the experiment. The abovedescribed situation may be the result of a relative increase in the abundance of small plankters such as microflagellates (as shown in Table 2), which settle slowly, and of the virtual elimination of grazing pressure by herbivores due to PCB toxicity which could 
reduce the production of fecal pellets with rapid sinking rates.

PCBs exert a detrimental effect on zooplankton. They eliminate zooplankters from the water column within $15 \mathrm{~d}$ after PCB addition. There is no evidence of recovery during the entire experimental period of $20 \mathrm{~d}$. Based on their copper experiment, Harrison and Davies (1977) showed that chronic inhibition of zooplankton feeding and subsequent decline in zooplankton biomass can be attributed to copper stress $(10 \mu \mathrm{g}$ $\left.\mathrm{l}^{-1}\right)$; copper-stressed zooplankton contributed only a small fraction to nutrient recycling. Several reports imply that zooplankters play an important role in the recycling of bioelements in a given ecosystem through ammonia and phosphate excretion - leading to rapid and direct exchange of nutrients between phytoplankton and zooplankton (Smith and Whitledge, 1977). Where zooplankters assume an important role for nutrient regeneration, a pollutant-caused reduction in zooplankton biomass could have a significant effect on a natural ecosystem.

Bacterial populations and their metabolic activities may recover quickly from mercury and copper perturbations (Vaccaro et al., 1977; Azam et al., 1977). Sayler et al. (1978) also documented a positive relation between PCB concentrations and the number of PCBdegrading bacteria. These results imply that PCB tolerant and PCB degrading bacteria might develop in a PCB-polluted ecosystem and may play an important role in the water column as well as in sediments.

Decomposition coefficients of sedimented matter were significantly inhibited by PCBs added in CEE E, but revealed recovery to the control level at the next sampling within $4 \mathrm{~d}$ (Table 3 ). Decomposition loss during suspension, expressed as $\mathrm{mg} \mathrm{C} \mathrm{m}{ }^{-2}$, also indicated a significant reduction in $\mathrm{PCB}$-treated CEE E, followed by an increase towards the end of the experiment due to both recovery from $\mathrm{PCB}$ stress and variation in gross sedimentation rate.

Acknowledgements. The authors wish to thank the CEPEX staff, particularly Miss J. Barwell-Clarke and Mr. R. Brown, for calculating ${ }^{14} \mathrm{C}$ and chlorophyll a data, and for counting zooplankton. We are grateful to Drs S. Taguchi, S. Kawai and Mr. F. Whitney for helpful critical comments on our manuscript. Many thanks are also extended to Dr. W. Cretney, Dr. D. Green and Mrs. M. McFarland for valuable discussions throughout the course of this research. This work was supported by Environmental Contaminant Contract Funds (Contract No. 07SB. FP833-8-0116), with C. S. Wong as Scientific Authority, awarded to Seakem Oceanography Ltd. The ECCF Committee made available contract funds and provided discussions and encouragement.

\section{LITERATURE CITED}

Azam, F., Vaccaro, R. F., Gillespie, P. A., Moussalli, E. I., Hodson, R. E. (1977), Controlled ecosystem pollution experiment: effects of mercury on enclosed water column. II. marine bacterio-plankton. Mar. Sci. Comm. 3: 313-329

Bidleman, T. F., Olney, C. E. (1974). Chlorinated hydrocarbons in the Sargasso Sea atmosphere and surface water. Science, N.Y 183: 516-518

Duke, T W., Lowe, J I., Wilson, A. J. Jr (1970). A polychlorinated biphenyl (Aroclor 1254) in the water, sediment and biota of Escambia Bay, Florida. Bull. environ. Contam. Toxicol 5: 171-180

Hansen, D. J., Parrish, P. R., Forester, J. (1974). Aroclor 1016: toxicity to and uptake by estuarine animals. Environ. Res. 7: $363-373$

Harding, L. W. Jr., Phillips, J. H. Jr (1978 a). Polychlorinated biphenyl (PCB) effects on marine phytoplankton photosynthesis and cell division. Mar. Biol. 49: 93-101

Harding, L. W. Jr., Phillips, J. H. Jr. (1978b). Polychlorinated biphenyl (PCB) uptake by marine phytoplankton. Mar. Biol. 49: 103-111

Harrison, W. G., Davies, J. M. (1977). Nitrogen cycling in a marine planktonic food chain: nitrogen fluxes through the principal components and the effects of adding copper. Mar. Biol. 43: 299-306

Iseki, K., Whitney, F., Wong, C. S. (1980). Biochemical changes of sedimented matter in sediment trap in shallow coastal waters. Bull. Plankt. Soc. Japan 27: 27-36

Jansson, B., Jensen, S., Olsson, M., Renberg, J., Sundstrom, G., Vaz, R. (1975). Identification by GC-MS of phenolic metabolities of $\mathrm{PCB}$ and p.p.-DDE isolated from Baltic guillemot and seal. Ambio 4: 93--97

Menzel, D. W., Anderson, J., Randtke, A. (1970). Marine phytoplankton vary in their response to chlorinated hydrocarbons. Science, N.Y. 167 : 1724-1726

Menzel, D. W., Case, J. (1977). Concept and design: controlled ecosystem pollution experiment. Bull mar Sci. 27: 1-7

Mosser, J. L., Fisher, N. S., Wurster, C. F. (1972). Polychlorinated biphenyls and DDT alter species composition in mixed culture of algae. Science, N.Y. 176: 533-535

O'Connors, H. B. Jr., Wurster, C. F., Powers, C. D., Biggis, D. C., Rowland, R. G. (1978). Polychlorinated biphenyls may alter marine trophic pathways by reducing phytoplankton size and production. Science, N.Y. 201: 737-739

Pavlou, S. P., Dexter, R. N. (1979). Distribution of polychlorinated biphenyls (PCB) in estuarine ecosystems. Testing the concept of equilibrium partitioning in the marine environment. Environ. Sci. Techol. 13: 65-71

Risebrough, R. W., Rieche, P., Peakall, D. B., Herman, S. G., Kirven, M. N. (1968). Polychlorinated biphenyls in the global ecosystem. Nature, Lond. 220: 1089-1102

Sayler, G. S., Thomas, R., Colwell, R. R. (1978). Polychlorinated biphenyl (PCB) degrading bacteria and PCB in estuarine and marine environments. Estuar. coast. mar. Sci. 6: $553-567$

Smayda, T J. (1970). The suspension and sinking of phytoplankton in the sea. Oceanogr. Mar. Biol. Ann. Rev. 8: 353-414

Smith, S. L., Whitledge, T E. (1977). The role of zooplankton in the regeneration of nitrogen in a coastal upwelling system off northwest Africa. Deep Sea Res. 24: 49-56

Strickland, J. D. H., Parsons, T. R. (1972). A practical handbook of seawater analysis, 2nd ed. Bull. Fish. Res. Bd Can. 167: $1-311$

Thomas, W. H., Seibert, D. L. R. (1977). Effects of copper on the dominance and the diversity of algae: controlled ecosystem pollution experiment. Bull. mar. Sci. 27: 23-33

Topping, G., Windom, H. L. (1977). Biological transport of copper at Loch Ewe and Saanich Inlet: controlled ecosystem pollution experiment. Bull. mar. Sci. 27: 135-141 
Vaccaro, R. G., Azam, F., Hodson, R. E. (1977). Response of natural marine bacterial populations to copper: controlled ecosystem pollution experiment. Bull. mar. Sci. 27: 17-22

Wong, C. S., Cretney, W., Iseki, K., Bauerfeind, E., McFar- land, M. (1981). Controlled experiment on pathways and sub-lethal effects of polychlorinated biphenyls (PCBs) in the marine enviromment. Presented at the Controlled exp. symposium, Sidney, B.C., in press

This paper was presented by Professor M. Anraku; it was accepted for printing on January 27, 1981 